\title{
Retorno à querela do Trieb: por uma tradução freudiana
}

\author{
Ivan Ramos Estêvão \\ Professor da Escola de Artes, Ciências e Humanidades da USP. \\ Psicanalista, Doutor em Psicologia Clínica pela USP.
}

Resumo: 0 artigo tem como intuito retomar 0 debate sobre a tradução dos textos de Freud, focando-se no conceito de Trieb, um dos mais importantes da psicanálise freudiana e também 0 de mais difícil tradução. Nossa tese é que, ao contrário do que os tradutores costumam apontar, a escolha entre os dois termos mais populares - instinto ou pulsão - não se dá por fatores técnicos, mas principalmente por motivos políticos. Optamos por abordar o tema a partir de três pontos da obra freudiana, a saber, a teoria do desejo e da responsabilidade, 0 debate entre sua posição natureza versus cultura e sobre a hereditariedade.

Palavras-chave: Psicanálise, Freud, tradução, pulsão, instinto, desejo, Trieb.
Abstract: The article has the intention go back to the debate about the translation of Freud's writings, focusing on the concept of Trieb, one of the most important in Freudian psychoanalysis and also the most difficult to translate. Our thesis is that unlike the translators usually claim, the choice between the two Portuguese most popular terms - instinto or pulsão - is not due to technical factors but primarily to political ones. We choose to approach this matter from three points of Freudian work, that is, the theory of desire and responsibility, the debate between the naturalist and the culture position and about the heredity theory.

Keywords: Psychoanalysis, Freud, translation, drive, instinct, desire, Trieb.

\section{1 - Introdução}

Em 2009 completaram-se 70 anos da morte de Freud. Isso significa que os direitos de publicação de seus textos caíram em domínio público. Trata-se de um fato a comemorar, principalmente por conta das já bem conhecidas deficiências da tradução Standard Brasileira das Obras Completas de Freud, publicada pela editora Imago, até então detentora dos direitos de publicação de Freud. Esperava-se que, com isso, surgissem grandes traduções, melhores inclusive do que a nova tradução empreendida também pela Imago sob a coordenação de Luiz Hanns. 
A nova tradução da Imago começou em 2004 antes mesmo das obras freudianas entrarem em domínio público. Contudo, apenas três volumes, organizados sob o tema "Escritos sobre a Psicologia do Inconsciente", foram lançados. A publicação cessou, ao que parece, sem perspectiva de continuar. Também são conhecidas as traduções de Marilena Carone, bem mais rigorosas do que as que se tinha na época, mas que eram lidas de modo "clandestino", pois não eram oficiais. Uma destas traduções já pôde ser lançada oficialmente, a de Luto e Melancolia. Há ainda as versões da L\&PM com dois grandes textos "sociais" de Freud, O Futuro de uma Ilusão e O Mal-estar na Cultura (em que Kultur é, enfim, traduzida por Cultura). Por último, há a tradução da Companhia das Letras, coordenada pelo germanista Paulo César de Souza, que é, talvez, a que tem rendido mais frutos e é aparentemente a substituta da tradução antiga da Imago.

Mas, para os que conhecem a tradução argentina da Amorrortu, que parece aglomerar em si as vantagens de outras traduções, fica a sensação de que ainda falta uma "boa" tradução para o português.

É sabido que a tradução Standard da Imago comete, desde seu início, um erro crucial: é uma tradução da tradução, ou seja, James Strachey coordena a tradução do original em alemão para o inglês que tem em suas notas de rodapé o ponto forte - e a Imago traduz da tradução inglesa, logo, duplamente tradittore. Mas há também erros primários como a inversão de frases, a alteração de contextos e, claro, a escolha infeliz de certos termos que transformam a escrita fluente de Freud num emaranhado estranho e pseudocientífico ${ }^{1}$. Assim, Besetzung é traduzido pelo estranho termo catexia; tanto Verdrängung como Unterdrückung são traduzidos como repressão ${ }^{2}$; Ich, UberIch e Es são subs-

1. Muito se comenta sobre esse assunto e vários exemplos reveladores das deficiências da tradução brasileira da Imago podem ser vistos nos textos de Marilena Carone. Cf., por exemplo, os artigos CARONE, M. "Freud em português: uma edição selvagem"; "Freud em português: ideologia de uma tradução"; "Freud em português: tradução e tradição" in SOUZA, P. C. (org.). Sigmund Freud e o Gabinete do Dr. Lacan. São Paulo: Brasiliense, 1990, pp. 160-188. Veja também o anexo da tradução de Luto e Melancolia feita por Marilena Carone. FREUD, S. Luto e Melancolia. São Paulo: Cosac Naify, 2012, pp. 90-97.

2. Nelson da Silva Jr. empreende uma discussão interessante sobre essa tradução. SILVA Jr., N. "Nota sobre a repressão nas traduções" in STEIN, C. O Psicanalista e seu Ofício. São Paulo: Escuta, 1988, p. 13-15. 
tituídos pelos termos latinos que se consagraram: Ego, Superego e $I d$; Kultur é traduzida como civilização e, finalmente, Trieb como instinto.

Seria interessante analisar a tradução de cada um dos termos citados acima, mas optamos por nos centrar, de novo, sobre o último deles, Trieb, pois nele está em jogo toda uma compreensão teórica que se modifica caso a tradução seja instinto ou pulsão ${ }^{3}$. A escolha de um termo em detrimento de outro, como procuraremos mostrar, não é sem consequência para o entendimento da obra e, dessa forma, para seu desenvolvimento posterior. Nossa tese aqui é, além disso, que a escolha da melhor forma de verter Trieb é bem mais política do que técnica, ao contrário do que em geral é proposto pelos tradutores. Algo que, atualmente, vem se tornando ainda mais forte ${ }^{4}$.

Seguiremos um conselho de Tavares $^{5}$ no que diz respeito a abordagem da questão. Assim, mesmo que sejamos "filiados" ao pensamento lacaniano, não nos valeremos dele em nossa argumentação senão,

3. Vários autores se dedicam a essa questão: Jacques Lacan, em seu seminário e outros trabalhos, adentra diversas vezes o tema. Cf., por exemplo, LACAN, J. "Televisão" in Outros Escritos. Trad. de V. Ribeiro. Rio de Janeiro: Zahar, 2002, p. 527. Laplanche e Pontalis tratam dela em seu famoso Vocabulário de Psicanálise. Cf. LAPLANCHE J. \& PONTALIS, B. P. Vocabulário de Psicanálise. Trad. P. Tamen. São Paulo: Martins Fontes, 1994, pp. 394-420. O próprio James Strachey se justifica, no primeiro volume das Obras Psicológicas Completas. Cf. STRACHEY, J. "Notas sobre alguns termos técnicos cuja tradução requer explicação" in FREUD, S. Edição Standard Brasileira das Obras Completas de Sigmund Freud, vol. I. Rio de Janeiro: Imago, 2006, pp. 31-2. Aqui no Brasil, temos, por exemplo, as posições de dois tradutores brasileiros de Freud, Paulo César de Souza e Luiz Alberto Hanns. Cf. SOUZA, P. C. As Palavras de Freud. São Paulo: Companhia das Letras, 2010, pp. 240-278; Cf. HANNS, L. A. "Comentários do Editor" in FREUD, S. Pulsões e Destinos da Pulsão. Obras Psicológicas de Sigmund Freud, vol. I. Rio de Janeiro: Imago, 2004, pp. 137-144. Pedro Heliodoro Tavares publicou um interessante artigo comparando as posições dos dois tradutores brasileiros, artigo com a qual concordamos em muitos pontos. Cf. TAVARES, P. H. As "derivas" de um conceito em suas traduções: o caso do Trieb freudiano. Trabalbos de linguística aplicada, Campinas, v. 50, n. 2, Dez. 2011, pp. 379-392.

4. Sobre esse processo de tradução de forma ideológica, além do artigo de Carone, supra citado, o texto de Bettelheim é praticamente obrigatório. Cf. BETTELHEIM, B. Freud e a Alma Humana. Trad. A. Cabral. São Paulo: Cultrix, 1982.

5. "O que fica a desejar é uma tradução que se proponha a ser, a partir dos recursos da língua portuguesa, fundamentalmente freudiana". TAVARES, P. H. 
no máximo, como mais um comentador entre tantos. O que estará em jogo aqui é Freud; portanto, trabalharemos o conceito de Trieb a partir do texto freudiano.

É certo que Trieb não é um termo de fácil tradução para o português, como confirma a celeuma em torno dele. É sabido que o próprio Freud admitia que era um termo invejado por outras línguas. Dessa forma, não caberia dentro de um artigo a análise de todos os pontos que dizem respeito a essa difícil tradução. Optamos, portanto, por partir de três pontos que consideramos centrais na obra de Freud, deixando outros de fora. De acordo com nossa suspeita, a tradução de Trieb como instinto ou pulsão tem diferentes efeitos teóricos e clínicos dentro de três campos na teoria freudiana. Traduzir Trieb como instinto possibilita um entendimento da posição freudiana em relação a três pontos diversos do que a tradução como pulsão.

1. No que diz respeito à teoria do desejo e da responsabilidade.

2. Sobre a problemática da cultura versus natureza.

3. Sobre a questão da corporeidade e da hereditariedade.

É, assim, a partir de algumas concepções e construções teóricas de Freud que poderemos situar e discutir melhor a tese acima.

\section{2 - Sobre a noção de Instinto}

Antes de tudo, consideramos importante fazer alguns apontamentos sobre o termo instinto em português, levando em conta que ele foi alvo de modificações ao longo do tempo e que hoje é provável que tenha uma conotação diferente da que tinha anteriormente, principalmente no que diz respeito ao avanço da genética e da biologia nas últimas décadas. Nesse sentido, sairemos um pouco da significação dicionarizada de instinto, mesmo porque ela já foi extensamente analisada tanto por Paulo César de Souza como por Luiz Alberto Hanns e Pedro H. Tavares, entre outros. Para tratarmos de como o termo instinto é visto na atualidade também não iremos diretamente ao seu aspecto técnico, por exemplo, como é utilizado em livros de biologia. Partiremos do universo popular. pois é disso que se trata, da apreensão

"As 'derivas' de um conceito em suas traduções: o caso do Trieb freudiano", p. 389. Grifos do autor. 
geral do termo. Assim, falaremos de como o termo instinto é veiculado na mídia e em livros de mais fácil acesso, de divulgação científica.

Assim, podemos dizer que é quase certo que instinto remete a impulso; também é certo que remete a algo ancestral, adaptativo e genético. Ora, nossa experiência dentro do ensino universitário (e também como transmissor de psicanálise) mostra que a tradução por instinto leva, na maioria das vezes, à interpretação pela via biológica dos textos de Freud. A questão da tradução se torna evidente quando se dá no campo do ensino (e sabemos que em psicanálise ensino e transmissão não se confundem, apesar de estarem aproximados). $\mathrm{O}$ próprio Paulo César de Souza aborda essa diferença ao comentar o livro de Bettelheim, Freud e a alma Humana: "Tendo nascido em Viena, em 1903, partilhando portanto da mesma língua e o ambiente cultural de Freud, [Bettelheim] emigrou para os Estados Unidos na década de 40. Lendo Freud em inglês, começou a notar que as versões produziram impressões diferentes das que formara lendo o original. Dando cursos teóricos de psicanálise, observava o mesmo efeito em seus estudantes ${ }^{6 \prime \prime}$. Trata-se de uma constatação empírica: os termos levam, como bem diz Paulo César de Souza, a todo um campo semântico associativo 7. Souza propõe inclusive um experimento que vivenciamos cotidianamente ao ensinar psicanálise nas universidades. Ele afirma que:

Um experimento revelador seria perguntar a um grupo de pessoas o que lhes evoca o termo "instinto", e depois fazer o mesmo com "pulsão". A "rede semântica" do primeiro seria bem mais rica, ligando-se aos campos léxicos de "impulso", "sexo", "ímpeto" etc., o mesmo não acontecendo com o segundo. ${ }^{8}$

Enfim, como dito, este experimento é feito continuamente e o campo semântico de instinto é, de fato, mais amplo que o de pulsão. Contudo, é evidente que o termo instinto remete fortemente ao campo do genético, hereditário, inato, incontrolável - termos que Paulo César de Souza não lembra no exemplo do "campo semântico"-, ou seja, uma disposição ligada ao campo da biologia.

Podemos dizer que essa tradução, principalmente para quem está iniciando os estudos nos textos freudianos, seria mais "palatável" na

6. SOUZA, P. C. (org.). Sigmund Freud e o Gabinete do Dr. Lacan, p. 158.

7. SOUZA, P. C. As Palavras de Frend, pp. 257-258.

8. Idem, p. 258. 
medida em que conjuga psicanálise com genética (a teoria dos genes), um dos grandes discursos da atualidade. Se a ideia de instinto já teve outras conotações, com os avanços dos estudos sobre hereditariedade e genética, seu vocabulário se tornou cada vez mais presente no cotidiano e o termo instinto ganhou muito espaço.

Expressões como "instinto de sobrevivência" ou "instinto materno" são corriqueiras. Em 2005, por exemplo, Dráuzio Varella apresentou um quadro intitulado "Mistérios do Instinto Humano", no conhecido programa dominical da Rede Globo, o "Fantástico". No texto do primeiro programa da série, Dráuzio diz:

O instinto humano: um conjunto de características que explica porque a gente é como é, porque a gente age de formas que a gente nem sabe explicar. Essa história não começa aqui, no mundo moderno e agitado em que a gente vive, mas nas savanas da África, onde surgiram os primeiros seres humanos. Neste cenário, nossos ancestrais deram seus primeiros passos. Lá, nossos instintos se formaram.

O instinto aqui é tratado como o é no uso atual da palavra: um comportamento herdado que está inscrito nos nossos genes e que teve uma função evolutiva. Ou seja, trata-se de uma ideia inatista/naturalista/organicista. Mas, longe de ser um comportamento irracional desregrado, o instinto tem uma função sempre bem definida (que pode, atualmente, ser disfuncional) e que persiste.

A ideia de instinto remete à questão dos genes e também a uma teoria da responsabilidade. Em 2000, Burnham e Phelan publicaram o livro Mean Genes, traduzido no Brasil por A culpa é da genética9. A tradução, não literal, não é obviamente casual. A ideia de culpa e responsabilidade estão sendo tratadas pela via da genética e, consequentemente, pela do instinto. O livro faz continuamente essa ligação entre genética e instintos.

Temos, com isso, dois elementos vinculados ao uso mais frequente da palavra instinto atualmente: ela é articulada à ideia de transmissão genética, biológica, hereditária ${ }_{i}$ e à de responsabilidade - ou não - de cada pessoa.

Assumindo certos critérios sobre o que é instinto, veremos que eles estão de fato presentes no ser humano, o que fica evidente em

9. BURNHAM, T. \& PHELAN, J. A culpa é da genética. Trad. C. I. Costa. Rio de Janeiro: Sextante, 2002. 
uma criança recém-nascida. Os instintos são inatos, universais e comumente vistos como irrefreáveis, a menos que por uma força externa - critério discutível -, e se referem a um conjunto complexo de comportamentos. Estas quatro características se encaixam, por exemplo, na ação de um bebê recém-nascido ao receber estímulo no rosto. Qualquer bebê, em qualquer parte do mundo, tende a virar a cabeça e fazer movimento de sucção. Além disso: qualquer bebê recém-nascido que for posto em um tanque d'água, nada. São instintos amplamente conhecidos e registrados. As razões da sua existência ainda são foco de debate, mas ambos são experimentalmente verificáveis. O que chama a atenção é que muito rapidamente esses instintos, inscritos na genética de cada pessoa, são suprimidos. Em poucos meses, um bebê que nasceu "sabendo" nadar, ao ser posto no mesmo tanque de água, afunda. O que ocorre nesse intervalo de tempo que irá se impor tão fortemente à biologia daquela criança, a ponto de poder levá-la à morte, mas não a reativar o instinto? E de forma tão prematura? É possível sustentar que alguns instintos são suprimidos e outros não? Que alguns instintos são irrefreáveis e outros não? Que alguns ficam latentes e só são ativados mais tarde na vida do indivíduo? Essas questões cabem aos geneticistas, etologistas e àqueles que justamente lidam com a psicologia cognitiva e do desenvolvimento. Mas cabem elas também ao psicanalista? Ou melhor, seriam essas as questões em jogo na psicanálise freudiana e que justificariam verter Trieb por instinto? Ou o que era instinto na época de Freud difere da ideia atual de instinto?

Seguindo o conselho de Tavares, retomaremos Freud para pensar uma tradução "freudiana" de Trieb.

\section{3 - Desejo e Responsabilidade}

A concepção atual de instinto parece apontar para uma teoria da responsabilidade. Basta, como vimos, um simples estudo da ideia de instinto no campo do senso comum para deparamos justamente com a problemática da responsabilidade. Nesse sentido, podemos tomar como exemplo o famoso artigo de Efe Hasse Walum e colaboradores, de setembro de 2008, publicado na Proceedings of the national academy of sciences ${ }^{10}$, que estabelece uma correlação entre o alelo 334 e o comportamento sexual de certos homens. A conclusão é que esse alelo au-

10. WALUM, E. H. et al. Proceedings of the National Academy of Sciences (PNAS), Sept./2008, vol. 105, no 37. 
mentaria a probabilidade de que seu portador não tenha relacionamentos estáveis. Motivo pelo qual este alelo ficou conhecido como o "gene da infidelidade masculina". Mais do que os resultados da pesquisa, o que parece entrar em jogo aqui é toda uma disseminação - não sem crítica, que fique claro - de que haveria uma tendência instintiva de certos homens para a infidelidade. A piada que se fez ecoar era: "Desculpe, querida, mas a culpa é do alelo 334".

Claro, temos aqui uma pesquisa que dá margem a muitos chistes, no entanto, ela diz respeito à questão do indivíduo diante do seu desejo. E temos base para suspeitar que Freud consideraria essa pesquisa, no mínimo, risível. Vejamos um pouco da teoria do desejo e sua articulação com o conceito de Trieb.

O desejo $[W u n s c h]$ é um conceito central na metapsicologia freudiana. Antes de qualquer coisa, podemos dizer que ele advém da experiência clínica e é, dessa forma, um operador para a compreensão dos fenômenos clínicos. Isso fica evidente já nos Estudos sobre a Histeria, a partir do caso Elisabeth Von R. ${ }^{11}$, onde Freud constrói parte de sua teoria do conflito psíquico a partir da premissa de que a histérica é dividida entre o que pode ser assimilado ao eu e aquilo que é vivido como insuportável e é recalcado, sendo assim, posto "fora" do eu. Freud denomina desejo tudo aquilo que é recalcado e todas as representações que se vinculam por associação a esse desejo.

Se até 1900 a ideia de desejo está sendo formulada por Freud (e pouco aparece em seus textos principais, dando espaço para etiologia sexual da neurose pela via da sedução infantil), a partir de Die Traumdeutung, o desejo se torna chave para sua compreensão de uma série de fenômenos externos à clínica, as tais "formações do inconsciente". O capítulo III do Die Traumdentung põe em cena essa questão e seu título é direto: "O Sonho é uma realização de desejo" [Der Traum ist eine Wunscherfiullung]. Ou seja, Freud posiciona o desejo como fator central na etiologia das neuroses, mas também como operador indispensável para compreender uma gama de fenômenos ditos "normais". Ao posicionar os sonhos como realizações do desejo, Freud pressupõe os desejos como um fenômeno universal e

11. FREUD, S. Studien über Hysterie, GW I. Estudios sobre la Histeria, AE II. Cito a Gesammelte Werke (Frankfurt: Fischer, 1999), seguida de minha tradução predileta, as Obras Completas da editora Amorrortu (Buenos Ayres, 2004-2006, $2^{\mathrm{a}}$ edição), citada como AE. Em ambos os casos, seguidos do número do volume. 
constitutivo. Atos falhos, sonhos e chistes são efeitos do desejo recalcado que retornam, assim como os sintomas neuróticos. E Freud se dá conta de que o que está em jogo nessa problemática do desejo é a questão da moral, pois é diante dela - uma moral calcada no recalque e no afastamento dos desejos edípicos - que um desejo ganha o estatuto de insuportável e é, portanto, passível de recalque.

Essa articulação é importante: é diante da lei simbólica, representada pela morte do UrVater e revivida por cada um na fase do complexo de Édipo (como bem nos apresenta Freud em Totem e Tabu ${ }^{12}$ ), que se instaura o recalque primário, que incide inicialmente sobre os desejos edípicos e que carrega consigo praticamente a lembrança de toda a infância. Essa lei simbólica, de proibição do incesto, é para Freud a base da moral e da cultura.

A entrada em cena do Todestriebe adicionou modificações importantes nesse construto teórico, sem, contudo, alterar essa articulação, em que o neurótico é essencialmente compreendido como um ser dividido e conflituoso, que tenta constantemente refrear os desejos que entram em contradição com sua moralidade (representado pelo supereu). Assim, o neurótico está sempre a favor e contra a cultura, de maneira ambivalente, e paga o preço com seu eterno mal-estar.

Ora, nesse breve panorama, vemos que está presente em Freud uma teoria da responsabilidade. Desde o momento em que o desejo ganha a categoria de algo insuportável e à medida que a teoria da cultura avança, a questão de o que se faz com o desejo se torna premente. A técnica analítica implica (mas não em sua totalidade) trazer à tona o desejo inconsciente, que se torna então responsabilidade do analisando. Colocar a moral no centro do tratamento é o mesmo que falar da responsabilidade: o que o neurótico faz ao recalcar o desejo é uma tentativa de se desresponsabilizar em relação a ele, excluindo-o de sua consciência. A análise o traz de volta, pondo em cena a possibilidade de uma dialetização da moral e a possibilidade de assumir outra posição diante do seu desejo.

E, se até aqui falamos de desejo, podemos dizer que ele é um dos pilares da teoria que sustenta o conceito freudiano de Trieb. Trieb e desejo são coisas diferentes, mas intimamente relacionadas. Podemos dizer que o desejo é, para Freud, um efeito de Trieb.

12. FREUD, S. Totem und Tabu, GW IX. Tótem y tabú, AE XIII. 
Afinal, como se engendra um desejo? É na articulação da teoria do recalque com a de Trieb que teremos uma possível resposta a essa questão. À medida que desenvolve a teoria do recalque, Freud se vê às voltas com dois conceitos que permanecerão (não inalterados, é verdade) até o final da teoria: o de representação [Vorstellung] e o de afeto [Affekt]. A representação se dá, em geral, em termos de um conjunto representacional (ou seja, não se trata de uma única imagem mnêmica, mas justamente de um complexo) que está interligado a um ou mais afetos. Mais adiante, os conceitos de representação e afeto se vinculam a um terceiro, o conceito de fantasia. É aí que Freud insere o conceito de Trieb.

Em Três Ensaios sobre a Teoria da Sexualidade, de 1905, Freud apresenta o conceito de Trieb, e que será mais tarde desenvolvido, em um texto de 1915, Triebe und Triebschicksale (e também em outros vários textos). Mas é em um texto de 1911, Formulações sobre os dois Princípios de Funcionamento Mental, que a articulação entre a teoria da representação, o conceito de fantasia e o de Trieb estará mais clara. A fantasia e o processo de pensamento serão formas de lidar com o Drang [pressão] de Trieb. Assim, podemos pensar Trieb como uma pressão no sentido de satisfação que exige uma ação modificadora da realidade externa da pessoa ${ }^{13}$. O pensar é então resultado da inibição pontual dessa ação que, agora sob o efeito do princípio de realidade, "encena" mentalmente o ato para que ele possa ser julgado e, então, barrado. Contudo, essa "encenação" - a fantasia - produz uma satisfação parcial que é acalentada pela pessoa. A fantasia em si já se torna um processo de descarga parcial de Trieb. Logo, o desejo seria a articulação, mediada pela representação e pelo afeto, entre Trieb e fantasia. O texto de 1908, Fantasias Histéricas e sua Relação com a Bissexualidade ${ }^{14}$, que junta fantasia e sintoma, é um bom exemplo desse processo de articulação entre fantasia, Trieb e desejo.

Dessa forma, não se trata simplesmente de um processo básico de descarga de Trieb, pela via da rememoração, mas sim de algo a mais, de um processo de vinculação e - digamos assim - de julgamento em

13. FREUD, S. Formulierungen über die Zwei Prinzipien des Psychischen Geschebens, GW VIII, p. 232-234. Formulaciones sobre los dos principios del acaecer psíquico, AE XII, pp. $225-6$.

14. FREUD, S. Hysterische Phantasien und ibre Beziebung sur Bisexualität, GW VII, p. 191-199. Las fantasias bistéricas y su relación con la bisexualidad, AE IX, p. 141-147. 
relação a como se dá essa vinculação. A fantasia é, por assim dizer, uma representação da ação que leva à satisfação de Trieb.

$\mathrm{O}$ que se pode derivar desse raciocínio é que Trieb é, antes de tudo, uma energia "desligada", que terá de se submeter ao processo de vinculação (ligação) para poder ser descarregada. Isso já pode ser pressuposto no Entwurf, quando Freud fala dos trilhamentos [Babnungen] ${ }^{15}$. Por meio desse processo, se constituem as vias pelas quais a ação motora poderá se tornar fonte de satisfação do Trieb. Assim, isso acontece por meio das representações, que podem ocorrer na forma de memórias e/ou de fantasias (e a distinção das duas será um trabalho necessário, mas árduo, para Freud, embora não caiba ser abordada aqui). Dessa forma, deve-se pensar, antes de tudo, que a ação que leva à satisfação de Trieb não é pré-concebida, ou seja, inata.

Veja bem: é possível pensar que a energia, que é a "matéria" da Trieb, seja inata, mas as vias de satisfação do Trieb não.

Por fim, isso fica mais evidente com a segunda teoria sobre Trieb. A teoria da Todestriebe traz características do Trieb que são pouco citadas no que tange à tradução. É bem conhecida a virada de 1920 e a proposta da sua segunda teoria. Se Freud antes tinha uma teoria calcada numa dualidade entre Selbsterbaltungstriebe ou Icbtriebe opostas à Sexualtrieb, a partir daí essa dualidade se desloca para a Todestriebe e a Lebenstriebe. A argumentação de Freud em favor dessa mudança é a de que, se na primeira teoria, Trieb está em jogo como princípio de funcionamento central do prazer, a clínica e diversos outros fenômenos psíquicos apontam para além desse princípio, ou seja, para o chamado princípio de Nirvana, que faz com que o sistema psíquico seja impelido, antes de buscar pelo prazer, a ligar/vincular [Bindung] o Trieb a um caminho de descarga.

$\mathrm{O}$ indivíduo tende a repetir um processo mental/comportamental indefinidamente (e daí seu caráter compulsivo) quando essa ligação não ocorre. Para Freud, isso é uma característica de Trieb, ou seja, precisar de uma ligação para ser satisfeita pela via do princípio de prazer. A ambiguidade do dualismo de Trieb não nos escapa nesse caso, pois Freud praticamente as iguala aqui, podendo ser possível pensar Trieb como uma só, que se diferencia pela ligação ou não. Dessa forma, Todestriebe seria o Trieb não ligada, enquanto Lebenstriebe seria Trieb ligada.

15. FREUD, S. Entwurf, GW Nachtragsband, p. 392. Proyecto de psicología, AE I, p. 344 . 
Não vamos discorrer mais nesse sentido, mesmo sabendo que há contestações a essa concepção, pois isso não nos é central nesse momento. O que importa é essa característica de Trieb como ligada ou não e a tendência conservadora de Trieb, que impele o organismo para seu estado anterior (eventualmente, a morte). Fica mais forte a ideia proposta antes por Freud de que o alvo [Ziel] de Trieb é sempre a satisfação, e esse alvo, como o objeto [Objekt], é absolutamente variável ${ }^{16}$. Ou seja, antes de qualquer coisa, Trieb pode ser considerada como uma coisa sem forma, talvez pura pressão [Drang], desligada, silenciosa até. Não haveria um conjunto pré-formatado que conduziria à satisfação, da qual o Trieb é desviada pelas pressões culturais.

Uma das conclusões a que podemos chegar é a de que há um processo que leva de Trieb ao desejo e, consequentemente, ao objeto de satisfação do desejo. Não haveria um objeto fixo e nem mesmo uma fantasia fixa (como no caso do susposto gene da infidelidade, cujo objeto seria necessariamente outra mulher). Essa fantasia e o desejo seriam da ordem de construções de cada um, de acordo com suas vivências e dariam ligação e direção ao Trieb. Daí a conhecida posição freudiana de que o objeto de Trieb é contingente.

Assim, quando Freud põe a problemática do desejo no centro de sua teoria da neurose (e, por que não, também no que diz respeito à psicose e à perversão), ele pensa o desejo como uma forma de descarga de Trieb. Uma vez que essas formas são variáveis, entra em jogo a questão da responsabilidade, mesmo em relação ao inconsciente. A pessoa submetida a um processo analítico se verá diante do impasse de assumir a responsabilidade por seu desejo, seja no sentido de colocá-lo em ação, seja reprimindo-o (ou seja, trata-se de uma negação que se opera agora de forma consciente) ou, ainda, sublimando- ${ }^{17}$.

Ora, sustentar uma teoria dos instintos dá margem para que a responsabilização seja pensada por outra via e se encaixe com mais "facilidade" na concepção organicista de responsabilidade. Na verdade, na de "desresponsabilização". Não se trata mais de um desejo que se constitui, mas praticamente de um desejo com o qual se nasce, de uma pressão adquirida em tempos ancestrais, que teria tido alguma

16. FREUD, S. Triebe und Triebschicksale, GW X, p. 215. Pulsiones y destinos de pulsión, AE XIV, p. 118.

17. FREUD, S. Über Psychoanalyse, GW VIII, p. 25-26. Cinco conferencias sobre psicoanálisis, AE XI, p. 24. 
função adaptativa ou vantagem em termos de seleção natural e que dirige a pessoa a um determinado comportamento complexo, que pode ser refreado, mas com certo custo. Como seria inscrito hereditariamente, o indivíduo não tem responsabilidade sobre ele. Mais que isso: nesse caso, não será uma terapia química (através de remédios) mais eficaz? Aqui, caberia a crítica lacaniana em relação à tradução: verter Trieb por instinto conduz a uma interpretação que pode apagar algo de mais original da teoria freudiana, a teoria de um sujeito que não é o eu, ou seja, a teoria do inconsciente. Mais que isso, não se trata de um inconsciente animalesco, tomado de pressões instintivas, mas, como bem demonstra a teoria dos sonhos, de um inconsciente que pensa, calcula, avalia. Não como a consciência, mas com regras próprias.

À luz da teoria freudiana do desejo, da fantasia e da ligação, poderíamos pensar Trieb como um instinto adquirido, o que é no mínimo muito estranho e até mesmo errôneo. Será que não seria melhor nomear de outra forma? Pulsão, talvez?

A ideia de instinto põe em cheque a questão da responsabilização e, portanto, tende a pôr em cheque a noção de desejo tal como formulada por Freud. A noção de instinto parece vincular a ideia de desejo a um conteúdo pré-definido, como se o Trieb fosse ligada de forma herdada a uma fantasia também herdada. Isso parece ser contrário à posição freudiana.

Logo, a tradução de Trieb por instinto ao invés de pulsão não remete a uma questão apenas técnica, mas a uma tomada de posição, que diminui (ou acaba) com o componente referente à responsabilidade. O instinto seria algo natural e irrefreável, enquanto Freud afirma constantemente as diversas formas de refrear, modificar e alterar a pulsão. Pagamos um preço por esta interdição, por essa perda de satisfação, mas é a partir daí que se pode falar de uma teoria da responsabilidade. Se Trieb é entendida a partir do desejo inconsciente, não se trata de algo inscrito em termos de uma genética, mas justamente de algo que desvia do biológico.

\section{4 - Naturalismo e Cultura: uma biologia estranha}

Como dito acima, Trieb é um termo de difícil tradução, pois mesmo Freud não foi muito preciso em relação à definição do conceito, alocando-o em princípio no limite entre o psíquico e somático, entre corpo e psique. Trieb pode assim ser lida como um ponto localizado no limite dos elementos naturais do corpo (a partir de 
uma perspectiva naturalista) e, portanto, como algo da ordem do biológico. Nesse sentido, Trieb se aproxima do instinto. Mas, se está no limite, Trieb também pode ser do campo do psíquico, efeito da conjunção do indivíduo com o social. Essa relação entre indivíduo e sociedade pode parecer tardia na teoria, mas não o é: desde o Entwurt ela está clara ${ }^{18}$, deixando explícita a importância do outro na constituição do indivíduo. É verdade que mesmo aí Freud vacila, como se vê numa passagem dos Três Ensaios sobre a Teoria da Sexualidade, na versão de 1905, em que ele minimiza os efeitos da educação face ao organicismo e à hereditariedade ${ }^{19}$.

Assim, seria Trieb da categoria do somático, o que a aproximaria da ideia de instinto, ou da ordem da psique e, portanto, da tradução por pulsão? Para tentar responder essa questão, convém fazermos antes outra pergunta: de que somático se trata em Freud, ou seja, de que corpo falamos?

Os textos iniciais de Freud sobre o fenômeno da histeria vão estudar justamente essa questão, qual é o corpo que está em jogo na neurose, e chegam a uma resposta que acreditamos ser surpreendente até hoje: não é o corpo biológico, onde imperam as leis da anatomia e fisiologia, mas outro corpo, que mais tarde será reconhecido como um corpo erotizado, transformando em campo de expressão dos desejos recalcados. A histeria confunde, subverte, critica o discurso anatômico e fisiológico da medicina justamente apresentando um corpo que parece não responder totalmente à sua biologia. Se é desse somático que Freud fala ao longo de sua obra, um somático invadido pela psique, então a Trieb parece estar mais fortemente ligada ao termo pulsão.

Contudo, elementos de um certo naturalismo freudiano estarão presentes em toda a obra. Frank Sulloway, em Freud, biólogo da mente ${ }^{20}$, explorará toda essa vertente freudiana, que depois será seguida por outros psicanalistas. Em 1920, Freud escreve um comentário que se tornou o paradigma desta posição:

18. FREUD, S. Entwurf, GW Nachtragsband, p. 456-457. Proyecto de psicología, AE I, pp. 414-5.

19. FREUD, S. Drei Abbandlungen zur Sexualtheorie, GW V, p. 78-79. Tres ensayos de teoría sexual, AE VII, pp. 161-2.

20. SULLOWAY, F. J. Frend, biologiste de l'esprit. Paris: Fayard, 1998. 
É provável que os defeitos de nossa descrição desapareceriam se no lugar dos termos psicológicos pudéssemos usar termos fisiológicos ou químicos. Mas é verdade que estes também pertencem a uma linguagem figurada com a qual estamos familiarizados há mais tempo e que são, talvez, mais simples. ${ }^{21}$

Este comentário, entre outros, serve de suporte para se manter a ideia de que Freud sempre esteve do lado de um certo naturalismo e de que suas proposições psicológicas são uma espécie de metáfora dos processos fisiológicos que ainda não teriam condições de ser descritos. Mark Solms, por exemplo, seguirá a risca essa tentativa de traduzir neuro-fisiologicamente as descobertas freudianas ${ }^{22}$.

Um texto anterior ao de 1920, O Interesse pela Psicanálise, de 1913, também contribuirá para pensar um Freud naturalista e aproximar a ideia de Trieb da de instinto. Na parte intitulada "O interesse biológico da Psicanálise", Freud fala de Trieb justamente como o ponto de ligação entre biologia e psicanálise, fazendo menção a este lugar fronteiriço entre o psíquico e o somático. A noção de apoio [Anlebnung] ganha destaque nesse contexto, pois, segundo Freud, as Selbsterhaltungstriebe servem de apoio para as Sexualtrieb, ou seja, o impulso sexual se apoia, em termos da escolha de objeto e do alvo [Ziel], nos impulsos de autoconservação, biológicos.

Mas a sexualidade, tal como vista nos Três Ensaios (texto que, aliás, apresenta o conceito de Trieb), é uma sexualidade que justamente escapa do natural. Ao afirmar a existência de uma sexualidade infantil e de um impulso sexual na criança, Freud lança mão do conceito de perversão, como é bem sabido. Contudo, ele desvincula o conceito de perversão de sua conotação moral para tratá-lo em sua acepção de desvio. Mas mesmo o termo desvio não pode ser tomado como uma patologia, ou seja, como um desvio do normal, pois o que Freud justamente parece defender aqui é a normalidade do desvio: a sexualidade humana é, já na infância, desviada de sua função reprodutora, logo, a "normalidade" seria uma sexualidade com outros fins, no caso, regida pelo princípio de prazer e não por um instinto sexual. Nesse sentido, o termo pulsão parece ser mais adequado. Há, contudo,

21. FREUD, S. Jenseits des Lustprinzips, GW XIII, p. 65. Más allá del principio del placer, AE XVIII, p. 58.

22. SOLMS, M. \& GAMWELL, L. Da Neurologia à Psicanálise. Trad. J. A. D. Pastore e M. Dancini. São Paulo: Iluminuras, 2008. 
um impulso sexual evidentemente desviado de sua função biológica. Essa posição se sustenta até a segunda teoria de Trieb, pois a partir daí a distinção entre impulsos de autopreservação e impulsos sexuais cai, dando margem aos impulsos sexuais contra os de morte. Ora, com essa queda, a noção de apoio também perde a sua função.

Assim, o naturalismo freudiano não remete à reprodução de uma biologia, pelo menos não aqui. A biologia, mais precisamente a fisiologia e a anatomia se tornam secundárias desde os Estudos sobre a Histeria. Já nos Três Ensaios isso se aprofunda. O termo instinto parece trazer de volta um fundamento biologista mais radical do que a proposta freudiana. Na verdade, contudo, Freud parece se afastar do naturalismo (mas não por completo).

Mesmo a segunda teoria de Trieb lida com aspectos biológicos, mas justamente propõe uma "nova" biologia que levaria em conta uma estranha tendência de todos os organismos para a morte. Freud faz "propostas" à biologia a partir da psicanálise, mas parece subverter as ideias biológicas.

O que chama mais a atenção é que, enquanto as ideias naturalistas se reduzem ao longo da obra, sendo alteradas, substituídas ou ainda transformadas em concepções "complicadas" (como a transmissão lamarckista de caracteres adquiridos, que veremos a seguir), as ideias culturais de Freud parecem seguir o caminho inverso, amplificando-se. Se, de início, Freud confere pouca importância aos fatores sociais na etiologia das neuroses, sabemos que, ao final da obra, Freud construiu toda uma teoria sobre a Cultura, chegando à conclusão de que a relação entre o indivíduo e a Cultura é determinante para sua constituição psíquica. O complexo de Édipo salta da condição de operador clínico para a de fase constitutiva do indivíduo e o supereu e o ideal de eu tornam-se cada vez mais relevantes. Se Trieb é o conceito entre o psíquico e o somático, podemos dizer que o supereu é o conceito fronteiriço entre o psíquico e o social.

Assim, a ideia de autoconservação deu lugar aos impulsos de vida (basicamente, sexuais), que se dirigem para as ligações entre indivíduos. A Cultura parece predominar em relação ao biológico na teoria freudiana e isso se evidencia no aumento da importância e da quantidade de seus textos ditos "sociais".

Ou seja, pensar Freud em termos de instinto é também considerar a própria ideia de instinto de forma errônea, cujos resultados seriam a imagem de um Freud que pouco conheceria de biologia, ou uma 
proposta biológica freudiana no mínimo equivocada (levando, inclusive, a descartar as teorias freudianas, como pretendem as teorias cognitivistas da atualidade).

Aqui nos encontramos com a posição antinaturalista de Freud. Se Freud fala em instinto, ele o faz a partir de uma concepção aparentemente muito distante da utilizada pela etologia, tal como a noção de instinto proposta por Steven Spinker, em O Instinto da Linguagem ${ }^{23}$, citado por Paulo César de Souza. Se uma tradução envelhece, podemos dizer que, nesse caso, a tradução de Trieb como instinto envelheceu na medida em que instinto foi ganhando contornos e peso dentro de um determinando campo, que adentra o campo popular, e já não equivale à noção de Trieb.

Tavares tem uma solução interessante para esse suposto impasse entre biologicismo e culturalismo: que Trieb seja sempre pensado como Freud o faz, ou seja, como fronteiriço ${ }^{24}$, nem tanto ao céu nem tanto ao mar. É o resgate da definição dada pelo próprio Freud em Trieb und Triebschicksale: a pulsão estaria no limite entre o psíquico e o somático, entre corpo e sistema psíquico. Mas, se assim o é, verter Trieb por pulsão nos parece mais satisfatório, pois distancia Trieb da biologia sem localizá-la totalmente na cultura. Tavares afirma: "(...) Trieb é designado como 'um conceito-fundamental convencional até o momento bastante obscuro' o que nos leva a pensar que uma tradução que tenha por meta um esclarecimento será uma tradução redutora. Em Neue Folge der Vorlesungen zur Einfübrung in die Psychoanalyse, Freud não deixará dúvidas quanto a esse caráter de indeterminação $(\ldots)^{\prime 25}$. Se a ideia de instinto não era precisa nos dias de Freud, como sugere Paulo César de Souza, hoje ela ganha maiores contornos, filiada a um certo modo de entender a teoria da evolução. Verter Trieb por pulsão põe em cena essa indeterminação do conceito

\section{5 - O problema da hereditariedade}

Sabemos que uma das influências de Freud foi Darwin e sua teoria da seleção natural. Podemos até supor que esse é o momento da

23. SPINKER, S. O Instinto da Linguagem. Trad. C. Berlinder. São Paulo: Martins Fontes, 2004.

24. TAVARES, P. H. "As 'derivas' de um conceito", p. 381.

25. Idem, ibidem. 
eclosão de um movimento naturalista, onde se aventa a possibilidade de explicar os fenômenos humanos como efeitos da natureza, passíveis de serem entendidos a partir das noções advindas da química e da física, que se articulariam com a biologia. Darwin não é o primeiro, mas trará para o campo da ciência uma nova concepção de hereditariedade, que produziria no homem o que Freud chamou de ferida narcísica. O homem não é mais a imagem e semelhança de Deus, mas sim um derivado de um ancestral em comum com os dos macacos.

Estando a hereditariedade tão em voga, que reflexo isso tem na recepção da teoria freudiana ${ }^{26}$ ? Isso nos importa na medida em que o termo instinto está extremamente ligado à noção de hereditariedade e também à sua versão atual, a genética, enquanto o termo pulsão prescinde dessa ligação. Um Freud mais voltado para a hereditariedade é, sem dúvida, um forte argumento em favor da manutenção da tradução de Trieb por instinto.

Não cabe aqui fazer um apanhado extenso sobre a questão da hereditariedade, mas podemos tecer certas considerações. Podemos dizer de pronto que a posição freudiana diante da ideia de hereditariedade é ambígua, sua importância aumenta e diminui de acordo com o andamento e com a necessidade da teoria, e chega a uma solução estranha para os dias atuais, que o põe numa situação muitas vezes chamada de Lamarckista.

A noção de hereditariedade é trazida à tona já nos escritos iniciais de Freud, como no verbete enciclopédico Histeria, de 1888, no qual um Freud charcotiano toma a hereditariedade como o fator principal na etiologia da histeria ${ }^{27}$. Em 1892, contudo, Freud assinala certa dúvida em relação a esse fator e, nas notas de rodapé do livro de Charcot, já deixa o fator hereditário claramente menos relevante ${ }^{28}$. O tal fator etiológico hereditário não estará ausente do livro de Freud escrito junto com Breuer, Estudos sobre a Histeria, mas é quase sempre tomado como um fator secundário ou muitas vezes não localizado.

26. Nesse sentido, há o interessante livro de Ritvo: Cf. RITVO, L. B. A Influência de Darwin sobre Freud. Trad. J. C. C. Guimarães. Rio de Janeiro: Imago, 1992. Assim como MAURY, L. Les émotions de Darwin à Freud. Paris: PUF, 1993.

27. FREUD, S. Hysterie, GW Nachtragsband, p. 82-83. Histeria, AE I, p. 55.

28. FREUD, S. Vorwort und Anmerkungen zur Übersetzung von J.-M. Charcot, Leçons du mardi de la Salpêtrière. GW Nachtragsband, p. 161. Prólogo y notas de la traducción de J.-M. Charcot, Leçons du mardi de la Salpêtrière, AE I, p. 173. 
Ou seja, Freud o leva em consideração, mas não o toma como objeto de estudo.

$\mathrm{Na}$ verdade, em Estudos sobre a Histeria, Freud parece bem mais interessado em apontar outros fatores determinantes para a neurose histérica que não a hereditariedade, distanciando-se da posição de Charcot. Os casos que Freud apresenta comumente têm sua etiologia em outros lugares, a saber, em lembranças recalcadas, desejos inconscientes e fantasias, entre outros. Em um artigo de 1895, Freud volta a falar sucintamente da hereditariedade, mas somente para passar o resto do texto trabalhando com os vários casos nos quais a hereditariedade é irrelevante ${ }^{29}$. Na verdade, a leitura de um bloco de textos de Freud em torno dessa data mostra que sua posição parece girar em torno de um mesmo ponto que pode ser exemplificado com o que ele diz em outro texto de 1895 :

De acordo com as concepções de Loewenfeld e de inúmeros outros, a etiologia dos estados de angústia deve ser buscada na bereditariedade. Ora, a hereditariedade é certamente imune a alterações; logo, se a neurose de angústia se cura sob tratamento, temos que concluir, segundo a argumentação de Loewenfeld, que sua etiologia não pode residir na hereditariedade. ${ }^{30}$

Toda a continuação do artigo não visa negar a hereditariedade, mas diminuir sua influência em relação à neurose. Freud argumenta em favor da sua etiologia sexual e se distancia cada vez mais da etiologia hereditária, que passa, dentre os seguidores de Charcot, a ter de lidar com a problemática de conferir à histeria um caráter crônico e incurável. Na verdade, podemos dizer que a hereditariedade se tornará um recurso ad boc, ou seja, toda vez que Freud deparar com um problema momentaneamente insolúvel, o que aparece é a suposição de que se trate de algo da ordem da hereditariedade.

Assim, o conceito de hereditariedade sobreviverá dentro da obra, mas num movimento contínuo de diminuição. Daremos um exemplo

29. FREUD, S. Über die Berechtigung von der Neurasthenie einen bestimmten Symptomenkomplex als «Angstneurose» abzutrennen. GW I, p. 325-342. Sobre la justicación de separar de la neurastenia un determinado sindrome en calidad de "neurosis de angustia", AE III, pp. 99-115.

30. FREUD, S. Zur Kritik der "Angstneurose". GW I, p. 366. A propósito de las críticas a la "neurosis de angustia", AE III, p. 130. 
nesse sentido. Mais acima fizemos menção à passagem dos Três Ensaios em que Freud parece dar prevalência aos fatores hereditários frente à educação na constituição psíquica. Vale a pena vermos a passagem toda:

Durante esse período de latência total ou apenas parcial erigem-se as forças anímicas que, mais tarde, surgirão como entraves no caminho da pulsão sexual e estreitarão seu curso à maneira de diques (o asco, o sentimento de vergonha, as exigências dos ideais estéticos e morais). Nas crianças civilizadas, tem-se a impressão de que a construção desses diques é obra da educação, e certamente a educação tem muito a ver com isso. Na realidade, porém, esse desenvolvimento é organicamente condicionado e fixado pela hereditariedade, podendo produzir-se, no momento oportuno, sem nenhuma ajuda da educação. Esta fica inteiramente dentro do âmbito que lhe compete ao limitar-se a seguir o que foi organicamente prefixado e imprimi-lo de maneira um pouco mais polida e profunda. ${ }^{31}$

Aqui, Freud é direto quanto à importância da hereditariedade e de como ela se sobrepõe à educação. Essa é a versão de 1905 do texto. Ora, 18 anos depois, em 1923, Freud terá uma posição completamente diferente. Em O Eu e o Isso ${ }^{32}$, ele apresenta de forma mais acabada sua teoria do complexo de Édipo e de castração, na qual os entraves do impulso sexual são efeitos de todo um jogo de relações e de processos psíquicos que pouco tem a ver com a hereditariedade.

Contudo, no caso do "Homem dos Lobos" e também na "Conferência XXIII", Freud atribui elementos do Édipo e do complexo de castração a esse movimento hereditário:

Tudo o que encontramos na pré-história das neuroses é que a criança lança mão dessa experiência filogenética quando sua própria experiência lhe falha. Ela preenche as lacunas da verdade individual com a verdade pré-histórica; substitui as ocorrências da sua própria vida por ocorrências da vida dos seus ancestrais. Concordo plenamente com Jung ao reconhecer a existência dessa herança filogenética; mas considero um erro metodológico agarrar-se a uma

31. FREUD, S. Drei Abbandlungen zur Sexualtheorie, GW V, p. 78-79. Tres ensayos de teoría sexual, AE VII, pp. 161-2. Op. cit..

32. FREUD, S. Das Icb und das Es, GW XIII, 235-289. El yo y el ello, AE XIX, pp. 13-59. 
explicação filogenética antes de esgotar as possibilidades ontogenéticas. ${ }^{33}$

Mas mesmo esse "resto" hereditário é complicado, pois se trata de um conteúdo ancestral que é ao mesmo tempo social. O que se tornou hereditário é a vivência da morte do UrVater, ou seja, um momento mítico, mas socializador. É como se inscrevêssemos em nosso organismo uma experiência histórica da humanidade (portanto, mais lamarckista do que darwinista). Dessa forma, mesmo o que Freud concede como hereditário é uma experiência adquirida. Mais do que isso, na citação sua posição fica evidente: deve-se esgotar as possibilidades ontogenéticas antes de supor as filogenéticas. Essa parece ser a posição freudiana ao longo da obra.

Concluindo, a hereditariedade aparentemente perde espaço dentro da teoria freudiana, que amplia o estudo de uma etiologia e teoria da constituição que se dá bem mais no seio de um processo socializador. A hereditariedade ganha novamente o estatuto de um conceito limítrofe entre o que é da biologia e o que é campo da psicanálise e, o que nos parece mais importante, Freud a dispensa toda vez que pode.

\section{6 - Considerações finais}

Articulando o que vimos acima, sobre a questão da hereditariedade em Freud, podemos chegar, de forma sucinta, às seguintes conclusões:

A hereditariedade se torna o limite da teoria psicanalítica, ou seja, ela entra nos momentos em que não é mais possível avançar em termos técnicos e conceituais; logo, a hereditariedade é um conceito ad boc, quer dizer, funciona como "tampão" para problemas insolúveis. Em todo o construto teórico, Freud caminha em direção à redução da questão da hereditariedade ao mínimo possível. Contudo, o fato é que Freud nunca abre mão completamente dela como um recurso para certas situações.

Quanto ao naturalismo e sua relação com a cultura, em Freud, o caminho é similar ao do conceito de hereditariedade: os recursos

33. FREUD, S. Aus der Geschichte einer infantilen Neurose, GW XII, p. 131. De la bistoria de una neurosis infantil, AE XVII, p. 89. 
naturalistas de Freud vão se reduzindo ao longo da obra sem, contudo, serem completamente abandonados. O movimento inverso também acontece, ou seja, a cultura é tomada como determinante para o funcionamento psíquico, tendo como seus agentes os pais, e ganha cada vez mais importância até tornar-se fundamental. Um exemplo interessante desse movimento pode ser visto a partir dos extremos de sua tese: se, em 1895, Freud se debruçava sobre o Entwurf e toda uma tentativa de pensar o inconsciente e os processos psíquicos em termos neuronais, na década de 30 , ele se dedicará intensamente aos chamados textos sociais, principalmente O Mal-estar na Cultura e Moisés e o Monoteísmo.

Isso terá influência, sem dúvida, sobre a teoria da responsabilidade: Freud não descarta fatores hereditários em sua teoria da constituição, não obstante, estes fatores não são levados em conta em sua clínica (e, quando raramente o são, é no início de sua teoria e apenas para apontar que diante deles nada pode ser feito). O que está em jogo em praticamente toda a teoria clínica é a posição do paciente diante de seu desejo, ou seja, o que ele faz e o que pode fazer diante de seu desejo. Se, frente a ele não há adaptação possível, isso nos leva, como Freud deixa claro em Mal-estar, novamente à pergunta: o que fazer?

Enfim, que conclusões podemos tirar daqui para pensar a tradução de Trieb?

Consequências possíveis da tradução de Trieb como instinto:

1. Biologiza a teoria, aproximando a psicanálise do saber entendido como científico e aparentemente facilitando o diálogo com as outras ciências biológicas e a medicina.

2. Vincula a concepção de homem de Freud a uma espécie de luta entre a natureza (numa perspectiva de homem como em parte um "animal humano") e a Cultura.

3. Diminui a responsabilidade sobre a dimensão do desejo, que, de certa forma, pode ser reduzida aos efeitos do organismo.

4. Aponta para uma leitura em que a hereditariedade ganha vigor, fortalecendo uma concepção de psicanálise que leva em conta o genótipo. Contudo, parece deixar de lado a posição freudiana diante da hereditariedade.

5. É menos rigorosa no que diz respeito ao efeito de repressão ou recalque de Trieb, pois o instinto contém em si a ideia de algo natural e irrefreável. 
6. O termo instinto seria mais impreciso para dar conta da fenomenologia de Trieb descrita por Freud.

Consequências possíveis da tradução de Trieb como pulsão:

1. Permite pensar o homem como um ser mais cultural, aproximando a psicanálise das chamadas ciências humanas, como sociologia, história, linguística, antropologia, etc.

2. Se harmoniza com a técnica que diz respeito à responsabilização diante do desejo: o desejo não é efeito de uma parte "animal" que resta no homem, mas um efeito da própria cultura e da relação com o outro.

3. É mais rigorosa no que diz respeito a algo que é passível de ser refreado, afastando-se, assim, da ideia de uma "natureza humana".

4. Remete a dois princípios centrais do conceito de Trieb: a pulsação constante, ou seja, algo que não cessa por completo nem diante da satisfação com o objeto; e aponta para seu efeito de pressão [Drang], que leva a um impulso.

5. Entra em consonância com a diminuição progressiva e constante que Freud dá à noção de hereditariedade, e também com a diminuição das ideias naturalistas.

Os três pontos explorados acima, a saber, a teoria da responsabilidade, a questão da hereditariedade e o suposto naturalismo freudiano não nos permitem resolver de modo definitivo o problema. $\mathrm{Na}$ verdade, Freud é ambíguo em seu tratamento dos três. Essa ambiguidade é, contudo, relativa, pois os três pontos parecem ter um mesmo vetor: diminuir o aspecto biológico da teoria e enfatizar o seu teor psicológico. Assim, Trieb sofre constantemente as vicissitudes da socialização e da cultura, bem mais intensamente do que as da biologia. A nosso ver, esse quadro complica a opção de verter Trieb por instinto e toda a carga biológica que ela denota.

Resta uma última questão. Por que supomos se tratar então de uma escolha política? Pois o que está em jogo vai além da questão técnica em termos de tradução: trata-se de assumir uma posição diante da comunidade científica e também da sociedade. Podemos dizer que o discurso médico/biológico tem uma aceitação bem maior diante de ambas do que o discurso psicanalítico. Se o discurso psicanalítico põe em debate a responsabilidade do indivíduo na forma como 
este lida com seu desejo inconsciente e defende que isso não é sem consequências na constituição psíquica de uma criança, o discurso médico/biológico tende a apagar a possibilidade dessa responsabilidade, que para eles é aparentemente inexistente. Uma "psicanálise" mais biológica, mais instintiva, é, por assim dizer, mais "palatável" ao discurso médico científico e ao discurso social. As discussões sobre a etiologia e o tratamento do autismo na França têm evidenciado o fator político e, por que não dizer, comercial dessa disputa entre psicanalistas e organicistas ${ }^{34}$.

Os três fatores, o hereditário, o naturalista e o da responsabilidade, parecem mais adequados ao discurso social, científico e médico quando se traduz o termo Trieb por instinto. Já esses mesmos fatores apontam para uma ruptura, uma subversão, um confronto, quando o termo tende a ser visto como pulsão, em seu formato incessante. Daí os winnicottianos preferirem a leitura de Trieb como instinto, privilegiando o biológico, e os lacanianos, pulsão, visto que entendem a linguagem e a cultura como os elementos que engendram a pulsão, afastando-se radicalmente do naturalismo.

Logo, ao contrário do que aponta Souza em seu As Palavras de Frend, a tradução de Trieb não é técnica, pelo menos em grande parte. A escolha dos tradutores é política, é uma tomada de posição diante do texto freudiano que interfere na compreensão da etiologia das patologias psíquicas e, consequentemente, na forma de tratamento proposta.

A posição de Paulo César de Souza aparece, de forma breve, em uma nota de rodapé de seu texto: "Estou convencido de que, se vivesse hoje, Freud leria obras de etologia e psicologia evolucionária, em vez de teorizações linguísticas e filosóficas ${ }^{\prime \prime 3}$. Ele, como sempre, usa a palavra de Freud para sustentar sua posição, ação legítima, sem dúvida, mas, como sabemos, sempre perigosa. Vejamos a quem Souza se dirige? Quem são aqueles que leem Freud à luz das teorizações linguísticas e filosóficas? Não há muito o que perguntar, trata-se de Lacan e de seus discípulos. Paulo César de Souza, mesmo não sendo psica-

34. Cf., por exemplo, o artigo do Le Point sobre a tentativa de regulamentação do tratamento do autismo na França. Le Point, Politique, 20/01/2012, France. http://www.lepoint.fr/politique/autisme-un-depute-ump-veut-interdire-1-accompagnement-psychanalytique-20-01-2012-1421333_20.php

35. SOUZA, P. C. As Palavras de Frend, p. 254. 
nalista, faz a sua aposta em um grupo dentro da psicanálise, e seu argumento é, sim, por um Freud biologist of the mind. Se a questão política não está explícita na escolha de Paulo César de Souza, esta se faz presente de forma indireta. Tavares (que considera a posição de Souza clara, ao contrário de nós) aponta justamente para a inserção do texto de Richard Wollheim, "O Gabinete do Dr. Lacan" no livro organizado por Paulo César de Souza como mais uma manifestação de sua escolha.

Além disso, se Paulo César de Souza dá como justificativa para verter Trieb por instinto o fato de instinto já ser uma palavra conhecida ${ }^{36}$, chegamos à conclusão que é justamente por isso que pulsão é um termo melhor. Não havendo uma palavra que se encaixe em Trieb e, sendo ela, uma palavra aberta a tantas possibilidades, que dá margem a tantas especulações, nada melhor do que propor uma nova palavra. Pulsão claramente já se tornou conhecida como "tradução" de Trieb. Afinal, qual o problema em mantê-la? Ora, se trata do termo escolhido por Lacan $_{i}$ se trata de um termo que não remete diretamente à biologia se trata de um termo que não se encaixa nos jargões médicos-científicos; se trata de um termo que exige mais interpretação, pois não é assimilado de imediato.

Se instinto remete a um saber já constituído, pulsão é sabidamente um termo que até pouco tempo não existia em português. É um aportuguesamento do francês pulsion, introduzido por Jacques Lacan na psicanálise. Nesse sentido, o termo pulsão, de início, em geral causa estranheza. Não é um termo familiar como instinto e as pessoas que iniciam seu estudo em psicanálise com a leitura de Freud não o identificam de imediato. Mas pela sonoridade (o que não quer dizer muita coisa), pulsão remete a dois sentidos: impulso, tal qual instinto; e pulsação (agora distinto do outro termo). A pulsão impulsiona e ao mesmo tempo pulsa, mantendo-se constante, mas diminuindo ou aumentando sua intensidade tal qual uma pulsação.

O termo pulsão acentua um Freud mais "humanista" e culturalista, que enfatiza a constituição do sujeito no bojo de uma sociedade e na relação com o outro do que na tentativa de controle de impulsos biológicos. O corpo aqui é um corpo atravessado pelo social, erotizado e menos biológico, bem menos reduzido a um organismo. A genética se torna um fator claramente secundário (senão, desnecessário)

36. SOUZA, P. C. As Palavras de Frend, p. 257. 
para a compreensão dos fenômenos psicológicos humanos. Não é à toa que Jacques Lacan é o defensor da ideia da tradução de Trieb como pulsão, que se aproximaria da sua concepção do homem como um ser atravessado pelo social, pela linguagem e pelo gozo. Trata-se, portanto, de uma escolha política.

Nos parece que, em termos de coerência teórica, dentro do conjunto da obra freudiana e levando em conta os pressupostos da clínica, o termo pulsão faz mais sentido, sem contudo deixar de levar em conta que a teoria apresenta (como não poderia deixar de ser) certas ambivalências, que levam Trieb a eventualmente se aproximar de instinto. Essa é a nossa posição. Não obstante, perguntamos ao leitor: e você, pulsão ou instinto?

\section{Referências bibliográficas}

BETTELHEIM, B.. Freud e a Alma Humana. Trad. A. Cabral. São Paulo: Cultrix, 19829.

BURNHAM, T. \& PHELAN, J.. A Culpa é da Genética. Trad. C. I. Costa. Rio de Janeiro: Sextante, 2002.

FREUD, S.. Gesammelte Werke. Frankfurt: Fischer, 1999. 19 vols. [GW]

FREUD, S.. Obras Completas. Buenos Aires: Amorrortu, 2004-20062. 24 vols. $[\mathrm{AE}]$

. Aus der Gescbicbte einer infantilen Neurose, GW XII. De la bistoria de una neurosis infantil, AE XVII.

. Das Ich und das Es, GW XIII. El yo y el ello, AE XIX.

. Drei Abbandlungen zur Sexualtheorie, GW V. Tres ensayos de teoría sexual, AE VII.

. Entwurf, GW Nachtragsband. Proyecto de psicología, AE I.

. Hysterie, GW I. Histeria, AE I.

. Hysterische Phantasien und ibre Beziebung sur Bisexualität, GW VII. Las fantasias bistéricas y su relación con la bisexualidad, AE IX.

XVIII. Jenseits des Lustprinzips, GW XIII. Más allá del principio del placer, AE

. Studien über Hysterie, GW I. Estudios sobre la Histeria, AE II.

Totem und Tabu, GW IX. Tótem y tabú, AE XIII.

XII.

Triebe und Triebschicksale, GW X. Pulsiones y destinos de pulsión, AE

Zur Kritik der "Angstneurose". GW I. A propósito de las críticas a la "neurosis de angustia", AE III. 

AE XI.

Über Psychoanalyse, GW VIII. Cinco conferencias sobre psicoanálisis, Formulierungen über die Zwei Prinzipien des Psychischen Geschebens, GW VIII. Formulaciones sobre los dos principios del acaecer psíquico, AE XII.

Vorwort und Anmerkungen zur Übersetzung von J.-M. Charcot, Leçons du mardi de la Salpêtrière. GW Nachtragsband. Prólogo y notas de la traducción de J.-M. Charcot, Leçons du mardi de la Salpêtrière, AE I.

Über die Berecbtigung von der Neurasthenie einen bestimmten Symptomenkomplex als «Angstneurose» abzutrennen. GW I. Sobre la justicación de separar de la neurastenia un determinado síndrome en calidad de "neurosis de angustia", AE III.

Edição Standard Brasileira das Obras Completas de Sigmund Freud, vol. I. Rio de Janeiro: Imago, 2006.

Pulsões e Destinos da Pulsão. Obras Psicológicas de Sigmund Freud. Edição Standard Brasileira das Obras Completas de Sigmund Freud, vol. XIV. Rio de Janeiro: Imago, 2004.

. Luto e Melancolia. Trad. M. Carone. São Paulo: Cosac Naify, 2012.

LACAN, J.. "Televisão" in Outros Escritos. Trad. de V. Ribeiro. Rio de Janeiro: Zahar, 2002.

LAPLANCHE J. \& PONTALIS, B. P. Vocabulário de Psicanálise. Trad. P. Tamen. São Paulo: Martins Fontes, 19942.

MAURY, L.. Les émotions de Darwin à Freud. Paris: PUF, 1993.

RITVO, L. B.. A Influência de Darwin sobre Freud. Trad. J. C. C. Guimarães. Rio de Janeiro: Imago, 1992.

SOLMS, M. \& GAMWELL, L.. Da Neurologia à Psicanálise. Trad. J. A. D. Pastore e M. Dancini. São Paulo: Iluminuras, 2008.

SOUZA, P. C.. As Palavras de Freud. São Paulo: Companhia das Letras, 2010.

(org.). Sigmund Freud e o Gabinete do Dr. Lacan. São Paulo: Brasiliense, 1990.

SPINKER, S.. O Instinto da Linguagem. Trad. C. Berlinder. São Paulo: Martins Fontes, 2004.

STEIN, C.. O Psicanalista e seu Ofício. São Paulo: Escuta, 1988.

SULLOWAY, F. J.. Frend, biologiste de l'esprit. Paris: Fayard, 1998.

TAVARES, P. H.. "As 'derivas' de um conceito em suas traduções: o caso do Trieb Freudiano". Trabalhos de linguística aplicada, Campinas, vol. 50, no 2, dez./2011.

WALUM, E. H., \& alli. Proceedings of the National Academy of Sciences (PNAS), Sept./2008, vol. 105, no 37. 
